\title{
Acidified Biogas Residues Improve Nutrient Uptake and Growth of Young Maize
}

\author{
Jens Torsten Mackens *(D), Bruno Maximilian Görlach and Karl-Hermann Mühling *(D) \\ Institute of Plant Nutrition and Soil Science, Kiel University, 24118 Kiel, Germany; \\ bgoerlach@plantnutrition.uni-kiel.de \\ * Correspondence: jtmackens@plantnutrition.uni-kiel.de (J.T.M.); \\ khmuehling@plantnutrition.uni-kiel.de (K.-H.M.); Tel.: +49-431-880-3189 (J.T.M. \& K.-H.M.)
}

\begin{abstract}
Biogas residues (BGR) contain a variety of plant nutrients and are, therefore, valuable fertilizers. However, ammonia $\left(\mathrm{NH}_{3}\right)$ emissions occur during slurry and BGR application. These emissions can be reduced by lowering the $\mathrm{pH}$ of the BGR. Acidification technology works well for slurry, but little is known about the effects on fertilizer properties of acidified BGR (ABGR). This study aimed to examine the impact of acidification on the chemical composition of BGR and its influence on plant growth of juvenile maize and the soil $\mathrm{pH}$, as well as the soluble soil phosphorous (P) and manganese (Mn), after application of ABGR. The soluble amount of nutrients in BGR was compared with that in ABGR. In an outdoor pot experiment, BGR and ABGR were incorporated in soil, and maize was grown for 8 weeks. Two different BGR P levels were compared with $\left(\mathrm{NH}_{4}\right)_{2} \mathrm{HPO}_{4}$ and a control treatment without additional P. BGR acidification increased dissolved amounts of P from $15 \%$ to $44 \%$, calcium from $6 \%$ to $59 \%$, magnesium from $7 \%$ to $37 \%$, and Mn from $2 \%$ to $15 \%$. The dry matter of ABGR-fertilized maize was 34\%, 45\% higher than that of BGR-fertilized maize. The soluble Mn content in the soil was $74 \%$ higher with the low ABGR dose and $222 \%$ higher with the higher ABGR dose than the BGR treatments. The fertilizer efficiency of ABGR was higher than that of BGR, indicating that the absolute amount of applied fertilizer could be reduced in systems using ABGR.
\end{abstract}

B.M.; Mühling, K.-H. Acidified Biogas Residues Improve Nutrient Uptake and Growth of Young Maize. Agronomy 2021, 11, 344. https:// doi.org/10.3390/agronomy11020344

Keywords: acidification; biobased fertilizer; nutrient availability; P fertilizer efficiency; starter fertilizer

Academic Editor: Francesc

Xavier Prenafeta Boldú

Received: 29 December 2020

Accepted: 11 February 2021

Published: 15 February 2021

Publisher's Note: MDPI stays neutral with regard to jurisdictional claims in published maps and institutional affiliations.

Copyright: (C) 2021 by the authors. Licensee MDPI, Basel, Switzerland. This article is an open access article distributed under the terms and conditions of the Creative Commons Attribution (CC BY) license (https:// creativecommons.org/licenses/by/ $4.0 /)$.

\section{Introduction}

Acidification of slurry has long been known to be an effective technique for reducing ammonia $\left(\mathrm{NH}_{3}\right)$ emissions in agriculture and improving the $\mathrm{N}$ utilization efficiency [1-3]. Nevertheless, the use of this technique has so far been limited to a few countries such as Denmark and the United Kingdom (UK). However, this changed in 2016, when European Union (EU) member states became legally obliged to significantly reduce their air pollutant emissions [4]. In order to achieve these reduction goals, the EU included slurry acidification in its catalog of measures as one of the best available technologies [5].

The emission reduction works on the principle that acid addition lowers the $\mathrm{pH}$ of the slurry, thereby shifting the dissociation equilibrium between $\mathrm{NH}_{3}$ and ammonium $\left(\mathrm{NH}_{4}\right)$ toward $\mathrm{NH}_{4}$, which is not volatile. The reduction of $\mathrm{NH}_{3}$ emissions can range from $15 \%$ to $98 \%$ depending on the type of slurry, the acid used, and the acidification technique $[2,3]$. This provides more $\mathrm{N}$ for plant nutrition in the field. Sulfuric acid $\left(\mathrm{H}_{2} \mathrm{SO}_{4}\right)$ is usually used for acidification, which has a double purpose according to Eriksen et al. [6]: reducing $\mathrm{NH}_{3}$ emissions and providing the crops with sulfur (S). The acidification of pig slurry in Denmark requires $\sim 5 \mathrm{~kg} \mathrm{H}_{2} \mathrm{SO}_{4} \cdot \mathrm{t}^{-1}$ of slurry to reduce the $\mathrm{pH}$ value to 5.5 . For the usual amount of slurry of 30-40 $\mathrm{m}^{3}$, this corresponds to a $S$ quantity of $48-64 \mathrm{~kg} \mathrm{~S} \cdot \mathrm{ha}^{-1}$ [6], in addition to the quantity of $S$ that is already contained in the slurry. However, considerably larger $S$ quantities have also been reported. For example, Pedersen et al. [7] reported that $382 \mathrm{~kg} \mathrm{~S} \cdot \mathrm{ha}^{-1}$ was applied as acidified cattle slurry that had been stored for long periods

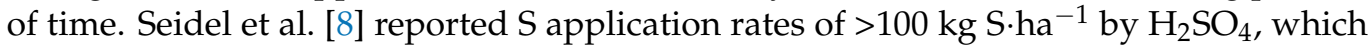


were applied in addition to the slurry. These $S$ levels exceed the $S$ requirements of crops, leaving excess $\mathrm{S}$ in the agricultural ecosystem.

Acidification of slurry also has further effects on slurry composition. While total nutrient concentrations of phosphorous $(\mathrm{P})$, calcium $(\mathrm{Ca})$, and magnesium $(\mathrm{Mg})$ remain the same [9], the dissolved contents of these nutrients are increased by slurry acidification [10], thereby increasing nutrient availability. Yield-increasing effects after fertilization with acidified pig slurry, as well as cattle slurry, have been shown in previous research [11,12].

Biogas residues (BGR) are particularly well suited to acidification, as they have an increased $\mathrm{NH}_{3}$ loss potential because of their high $\mathrm{pH}$ values. During anaerobic digestion, the $\mathrm{pH}$ of slurry increases by $0.5-2$ units because of the formation of ammonium carbonate $\left(\left(\mathrm{NH}_{4}\right)_{2} \mathrm{CO}_{3}\right)$ and the conversion of $\mathrm{CO}_{3}{ }^{2-}$ and $2 \mathrm{H}^{+}$to $\mathrm{H}_{2} \mathrm{O}$ and $\mathrm{CO}_{2}$ [13]. Furthermore, the solubility of some nutrients, especially $\mathrm{P}$, changes during anaerobic digestion. Güngör et al. [14] found that, in anaerobic digestion of dairy cattle slurry, the proportion of struvite increased from $43 \%$ to $78 \%$ of total P. In addition, they found that there was a simultaneous shift within the $\mathrm{Ca}-\mathrm{P}$ fractions from the poorly water-soluble brushite $\left(\mathrm{CaHPO}_{4} \cdot 2 \mathrm{H}_{2} \mathrm{O}\right)$ to the water-insoluble hydroxylapatite $\left(\mathrm{Ca}_{5}\left(\mathrm{PO}_{4}\right)_{3} \mathrm{OH}\right)$ [14]. Wastewater research has shown that, during the formation of $\mathrm{P}, \mathrm{Mg}$, and $\mathrm{Ca}$ crystals, at least seven different crystalline phases can precipitate [15]. The acidification of BGR is particularly favorable to reduce this precipitation. However, the effects of acidification on the nutrient pool of BGR and how this affects the nutrient availability for maize remain unknown. It can be assumed that the acidification of BGR leads to similar effects as the acidification of slurry, whereby the required amount of acid is likely to be larger than that for slurry. Stevens et al. [16] demonstrated that the acid demand correlates positively with the $\mathrm{NH}_{4}$ content in slurry. Furthermore, the amount of acid required to lower the $\mathrm{pH}$ value depends on the complex buffer system in the slurry and BGR. In experiments with pig and cattle slurry and BGR, Sommer and Husted [17] showed that the buffer system mainly consists of $\mathrm{NH}_{4}-\mathrm{N}$, carbonates, phosphates, and volatile fatty acids.

The aim of the current study was to investigate the effects of BGR acidification on macro- and micronutrient solubility in BGR and the effects on plant growth, as well as the nutrient acquisition, in young maize plants fertilized with acidified biogas residues (ABGR). Two fertilization levels were examined to check whether the increased use of sulfuric acid $\left(\mathrm{H}_{2} \mathrm{SO}_{4}\right)$ has negative effects on plant growth. We hypothesized the following: (1) acidification of BGR leads to an increase of the dissolved P-fraction in ABGR; (2) this leads to a concomitant increase of the dissolved conjugates of $\mathrm{P}$, namely $\mathrm{Ca}, \mathrm{Mg}$, manganese $(\mathrm{Mn})$, iron $(\mathrm{Fe})$, and zinc $(\mathrm{Zn})$; (3) application of ABGR will decrease soil $\mathrm{pH}$; (4) fertilization leads to a higher biomass production of young maize plants compared with untreated BGR because of the improved nutrient solubility in ABGR. The results of this study can help to dispel uncertainties regarding the effects of BGR acidification and, thus, promote this ammonia emission-reducing technology for practical applications in agriculture, especially since previous studies always focused on $\mathrm{N}$ and/or P. In this study, the effects of acidification on all essential nutrients are highlighted, because acidification of BGR creates a new multi-element fertilizer.

\section{Materials and Methods}

\subsection{Digestate Treatment and Analysis}

BGR was sampled from an agricultural biogas plant in the federal state of SchleswigHolstein, Northern Germany. Substrates of the biogas plant were maize silage, pig slurry, dry chicken feces, and forage winter rye, which were anaerobically digested for 70 days under mesophilic conditions $\left(41^{\circ} \mathrm{C}\right)$. After sampling, BGR was homogenized with a mixer and the $\mathrm{pH}$ was measured potentiometrically with a $\mathrm{pH}$ meter (Orion Model 520A Orion Research, Boston, MA, USA). Subsamples were acidified from initial $\mathrm{pH} 8.3$ to $\mathrm{pH} 5.5$ by adding $18 \mathrm{M} \mathrm{H}_{2} \mathrm{SO}_{4}$ dropwise under continuous stirring with $\mathrm{pH}$ control. Octanol $\left(\mathrm{C}_{8} \mathrm{H}_{18} \mathrm{O}\right)$ was used as a defoaming agent with an application rate of $1 \mathrm{~mL} \cdot \mathrm{kg}^{-1}$ ABGR. BGR was also treated with octanol to compensate for possible effects. For the analyses of nutrients 
in (A)BGR, the method of Dou [18] was modified. After reaching the target $\mathrm{pH}$ of 5.5, samples were freeze-dried (Gamma 1-20 (LMC-2), Martin Christ Gefriertrocknungsanlagen $\mathrm{GmbH}$, Osterode am Harz, Germany) and then milled to a fine powder (MM2, Retsch, Haare, Germany). For total nutrient determination, a digestion with aqua regia was performed in a microwave oven at $180^{\circ} \mathrm{C}$ for $20 \mathrm{~min}$ (1.800 W, MARS 6, Xpress, CEM, Matthews, MC, USA). Water-soluble nutrient concentrations were determined after shaking $0.3 \mathrm{~g}$ of the freeze-dried ABGR or BGR samples in $30 \mathrm{~mL}$ of distilled water for $16 \mathrm{~h}$. Samples were centrifuged at $2970 \times g$ for $25 \mathrm{~min}$ (Suprafuge 22/20, Heraeus Sepatech $\mathrm{GmbH}$, Osterode, Germany) and the supernatant was decanted. The P concentrations of all extracts were determined photometrically with a continuous flow analyzer (Skalar Analytical B.V., Breda, the Netherlands) by using the modified molybdenum-ascorbic acid blue method [19]. The $\mathrm{Ca}^{2+}$, copper $\left(\mathrm{Cu}^{2+}\right), \mathrm{Fe}^{2+}$, potassium $\left(\mathrm{K}^{+}\right), \mathrm{Mg}^{2+}, \mathrm{Mn}^{2+}$, and $\mathrm{Zn}^{2+}$ contents were quantified with an atomic absorption spectrometer (AAS 5EA Thermo Electron S, Carl Zeiss, Jena, Germany). All extractions were performed and analyzed at least in duplicate.

\subsection{Experimental Design of the Pot Experiment}

An outdoor pot experiment (covered by a wire cage) was carried out at the experimental station of the Institute of Plant Nutrition and Soil Science, Kiel University, Kiel $\left(54^{\circ} 20^{\prime} 50^{\prime \prime}\right.$ north $(\mathrm{N}), 10^{\circ} 6^{\prime} 55^{\prime \prime}$ east (E)). Mitscherlich pots were filled with $6 \mathrm{~kg}$ of air-dried and $<4 \mathrm{~mm}$ sieved soil, which had a loamy sand texture with $74.7 \%$ sand, $16.5 \%$ silt, and $8.8 \%$ clay. The soil used for the experiment had calcium acetate lactate-extractable $\mathrm{P}$ and $\mathrm{K}$ [20] contents of 8.7 and $9.3 \mathrm{mg} \cdot 100 \mathrm{~g}^{-1}$ soil, respectively, and a $\mathrm{CaCl}_{2}$-extactable $\mathrm{Mg}$ content [21] of $5 \mathrm{mg} \cdot 100 \mathrm{~g}^{-1}$ soil. The diethylenetriaminepentaacetic acid-extractable micronutrient contents of boron (B), $\mathrm{Cu}, \mathrm{Mn}, \mathrm{Fe}$, and $\mathrm{Zn}$, analyzed according to the method described in Blume [21], were 0.14, 2.1, 65.1, 166.6, and $1.7 \mathrm{mg} \cdot \mathrm{kg}^{-1}$ soil, respectively. Soil $\mathrm{pH}$ measured in $\mathrm{CaCl}_{2}$ solution [21] was 6.6.

The experiment was designed for $\mathrm{P}$ because, during the early growth stages of maize, $P$ can be growth-limiting [22]. The experiment was based on total P (TP) and included two P application rates of 200 and $400 \mathrm{mg}$ P per pot for NPK treatments, as well as for BGR and ABGR treatments and a control (NK treatment) without additional P (Table 1). These P fertilizer rates have been proven in previous studies using $6 \mathrm{~kg}$ Mitscherlich pots to study the fertilizer effects of biobased fertilizers [23-25]. According to the TP concentration in the BGR, 155 and $310 \mathrm{~g}$ of fresh matter (FM) BGR was required for fertilization.

Table 1. Treatment codes and application rates of the applied fertilizers ${ }^{\mathrm{a}}$.

\begin{tabular}{|c|c|c|c|c|c|c|}
\hline \multirow{2}{*}{ Treatment Code } & Total P & FM BGR or ABGR & DAP & $\mathrm{NH}_{4} \mathrm{SO}_{4}$ & $\mathrm{KCl}$ & \multirow[t]{2}{*}{$\mathrm{K}_{2} \mathrm{SO}_{4}$} \\
\hline & $\left(\mathrm{mg} \cdot \operatorname{pot}^{-1}\right)$ & \multicolumn{4}{|c|}{$\left(g \cdot \operatorname{pot}^{-1}\right)$} & \\
\hline NK & 0 & 0 & 0 & 4.76 & 2.29 & 2.48 \\
\hline $\mathrm{NPK}_{200}$ & 200 & 0 & 1 & 3.92 & 2.29 & 2.29 \\
\hline $\mathrm{BGR}_{200}$ & 200 & 155 & 0 & 2.38 & 1.77 & 2.07 \\
\hline $\mathrm{ABGR}_{200}$ & 200 & 155 & 0 & 2.38 & 1.77 & 2.07 \\
\hline $\mathrm{NPK}_{400}$ & 400 & 0 & 2 & 3.07 & 2.29 & 2.29 \\
\hline $\mathrm{BGR}_{400}$ & 400 & 310 & 0 & 0.00 & 1.25 & 1.25 \\
\hline $\mathrm{ABGR}_{400}$ & 400 & 310 & 0 & 0.00 & 1.25 & 1.25 \\
\hline
\end{tabular}

Mineral fertilizers were applied before filling the pots by mixing the soil and fertilizer in a mixer. Acidification of BGR was carried out 2 days before sowing by slowly adding $18 \mathrm{M} \mathrm{H}_{2} \mathrm{SO}_{4}$ while stirring until the intended $\mathrm{pH}$ reached 5.5. Before application, ABGR $\mathrm{pH}$ was readjusted because the $\mathrm{pH}$ increased overnight. A total of $17.33 \mathrm{~mL} \mathrm{H}_{2} \mathrm{SO}_{4} \cdot \mathrm{kg}^{-1}$ BGR was used for acidification. One day before sowing, BGR and ABGR were applied to the soil surface and immediately incorporated into the upper $7 \mathrm{~cm}$ of soil.

The pot treatments were set up in a randomized complete block design to consider possible position effects. Each treatment was carried out in five replicates. Two maize seeds 
(Zea mays L. var. Keops) were sown per pot at $3 \mathrm{~cm}$ depth. Five days after germination, the poorly developed seedlings in each pot were removed, leaving one plant per pot for the remainder of the trial. The plants were exposed to natural weather conditions. Irrigation was carried out on demand. Surplus irrigation water and rain could freely drain through the Mitscherlich pots. Leached water was collected and returned to the plants. Temperatures during the experiment were monitored with a LogTag Data Logger (Trix-16, CiK Solutions $\mathrm{GmbH}$, Karlsruhe, Germany). Temperatures ranged from 8.3 to $38^{\circ} \mathrm{C}$ and had an average of $20.6^{\circ} \mathrm{C}$.

\subsection{Plant Sampling and Analysis}

Eight weeks after germination, the plants were cut above ground and weighed to determine the fresh weight. The dry weight $(\mathrm{DM})$ was determined after oven-drying at $65{ }^{\circ} \mathrm{C}$ until the weight became constant. Afterward, samples were milled to a fine powder (Cyclotec 1093, Foss Tecator, Höganäs, Sweden) and stored for further analysis.

To determine the total $\mathrm{N}$ and $\mathrm{S}$ concentrations, 5-10 mg of plant powder was weighed into tin capsules and measured in duplicate with a CNS elemental analyzer (Flash EA 1112 NCS, Thermo Fisher Scientific, Waltham, MA, USA).

For mineral analysis, $200 \mathrm{mg}$ of plant material was digested with $10 \mathrm{~mL}$ of $65 \% \mathrm{HNO}_{3}$ (ROTIPURAN ${ }^{\circledR}$ p.a., ISO) in a microwave oven at $190^{\circ} \mathrm{C}$ for $45 \mathrm{~min}(1800 \mathrm{~W}$, MARS 6, Xpress, CEM, Matthews, MC, USA). The $\mathrm{Ca}^{2+}, \mathrm{Cu}^{2+}, \mathrm{Fe}^{2+}, \mathrm{K}^{+}, \mathrm{Mg}^{2+}, \mathrm{Mn}^{2+}$, and $\mathrm{Zn}^{2+}$ contents were quantified by AAS and the $\mathrm{P}$ content was quantified using inductively coupled plasma-mass spectrometry (Agilent Technologies 7700 Series, Böblingen, Germany). The reliability of the procedure was checked by analysis of the reference material (NCS DC 73350). The relative effectiveness (RPE, \%) was calculated to rank the P fertilization with BGR/ABGR compared with NPK as follows:

$$
\mathrm{RPE}=\frac{\left(\mathrm{P}_{\text {uptakeBGR/ABGR }}-\mathrm{P}_{\text {uptakeNK }}\right)}{\left(\mathrm{P}_{\text {uptakeNPK }}-\mathrm{P}_{\text {uptakeNK }}\right)} \times 100 .
$$

\subsection{Soil Sampling and Analysis}

To take a homogeneous soil sample, the entire soil volume of each pot was mixed in a mixer at the end of the experiment. For analysis of soil $\mathrm{pH}$ and all other chemical soil parameters, the soil samples were sieved $(<2 \mathrm{~mm})$ and then air-dried. Soil $\mathrm{pH}\left(1: 2.5 \mathrm{CaCl}_{2}\right)$ [21] was measured with an Orion Model 520A pH meter (Orion Research, Boston, MA, USA). The soluble $\mathrm{Mn}$ and $\mathrm{P}$ compounds of the soil were extracted using the method described by Houba et al. [26]. For the extraction with $0.01 \mathrm{M} \mathrm{CaCl}_{2}, 5 \mathrm{~g}$ samples of air-dried soil were shaken for $2 \mathrm{~h}$ with $50 \mathrm{~mL}$ of $\mathrm{CaCl}_{2}$ solution. The extracts were then filtered through P-free filter papers (Machery-Nagel, MN 619 G). The Mn content in the extracts was quantified with AAS (AAS 5EA Thermo Electron S). The P content in the soil extract was measured photometrically at a wavelength of $880 \mathrm{~nm}$ (Skalar Analytical B.V., Breda, the Netherlands) using the molybdenum blue method described by Murphy and Riley [19].

\subsection{Statistics}

The statistical software R Version 3.6.0 [27] was used to evaluate the data. The evaluation started with the definition of an appropriate statistical mixed model $[28,29]$ for plant and soil samples and a linear model for BGR. The data were assumed to be normally distributed and to be heteroscedastic according to a graphical residual analysis. The statistical model for plant and soil samples included the fertilizer variable as the fixed factor, and the blocks were regarded as random factors. For ABGR, the $\mathrm{H}_{2} \mathrm{SO}_{4}$ treatments were regarded as fixed factors. On the basis of these models, a pseudo $R^{2}$ was calculated [30] and an analysis of variance (ANOVA) was conducted, followed by multiple contrast tests (e.g., [31]) to separately compare the different levels of the influencing factors. Differences between means were considered statistically significant at the $p \leq 0.05$ level. 


\section{Results}

\subsection{Effects of Acidification on BGR Composition}

Acidification led to a significant increase of the $\mathrm{H}_{2} \mathrm{O}$-soluble macronutrients $\mathrm{P}, \mathrm{Ca}$, and $\mathrm{Mg}$; however, the solubility of $\mathrm{K}$ was not affected by acidification (Table 2). In the case of the analyzed micronutrients, only the Mn solubility was significantly increased. A significant reduction in $\mathrm{H}_{2} \mathrm{O}$-solubility was found in $\mathrm{Cu}, \mathrm{Fe}$, and $\mathrm{Zn}$. In addition, the acidification led to a significant change in the color of the ABGR (Appendix A, Figure A1).

Table 2. Total and $\mathrm{H}_{2} \mathrm{O}$-soluble nutrient contents of the analyzed biogas residue (BGR). Values of macronutrients are given as $\mathrm{g} \cdot \mathrm{kg} \mathrm{DM}{ }^{-1}$ (dry matter) and micronutrients as $\mu \mathrm{g} \cdot \mathrm{g} \mathrm{DM}^{-1}$. Values in parentheses represent the percentage of $\mathrm{H}_{2} \mathrm{O}$-soluble nutrients of total. Asterisks $\left({ }^{* *} p \leq 0.001\right)$ indicate significant differences between acidified biogas residue (ABGR) and BGR. n.s, not significant; n.d, not detected. Values are the means of at least two replicates. The standard deviation is not indicated to improve the readability of the table.

\begin{tabular}{|c|c|c|c|}
\hline \multirow{2}{*}{ Parameter } & \multirow{2}{*}{ BGR Total Nutrient Content } & BGR & ABGR \\
\hline & & \multicolumn{2}{|c|}{$\mathrm{H}_{2} \mathrm{O}$-Soluble Nutrient Content } \\
\hline DM (\%) & 8.13 & n.d & n.d \\
\hline $\mathrm{pH}$ & 8.3 & 8.3 & 5.5 \\
\hline Total N $\left(\mathrm{g} \cdot \mathrm{kg} \mathrm{DM}{ }^{-1}\right)$ & 82 & n.d & n.d \\
\hline $\mathrm{NH}_{4}-\mathrm{N}\left(\mathrm{g} \cdot \mathrm{kg} \mathrm{DM}{ }^{-1}\right)$ & 51.7 & n.d & n.d \\
\hline $\mathrm{P}\left(\mathrm{g} \cdot \mathrm{kg} \mathrm{DM} \mathrm{DM}^{-1}\right)$ & 15.9 & $2.4(15)$ & $7.1(44) * * *$ \\
\hline $\mathrm{K}\left(\mathrm{g} \cdot \mathrm{kg} \mathrm{DM}^{-1}\right)$ & 42.75 & $40.33(94)$ & $36.84(86)$ n.s \\
\hline $\mathrm{S}\left(\mathrm{g} \cdot \mathrm{kg} \mathrm{DM} \mathrm{DM}^{-1}\right)$ & 6.06 & n.d & n.d \\
\hline $\mathrm{Ca}\left(\mathrm{g} \cdot \mathrm{kg} \mathrm{DM} \mathrm{DM}^{-1}\right)$ & 52.52 & $3.23(6)$ & $31.21(59)^{* * *}$ \\
\hline $\mathrm{Mg}\left(\mathrm{g} \cdot \mathrm{kg} \mathrm{DM}{ }^{-1}\right)$ & 5.87 & $0.39(7)$ & $2.16(37) * * *$ \\
\hline $\mathrm{Cu}\left(\mu \mathrm{g} \cdot \mathrm{g} \mathrm{DM}^{-1}\right)$ & 115.6 & $47.24(41)$ & $10.99(10)^{* * *}$ \\
\hline $\mathrm{Fe}\left(\mu \mathrm{g} \cdot \mathrm{g} \mathrm{DM}^{-1}\right)$ & 2637 & $324(12)$ & $29(1)^{* * *}$ \\
\hline $\operatorname{Mn}\left(\mu \mathrm{g} \cdot \mathrm{g} \mathrm{DM}^{-1}\right)$ & 405.46 & $6.5(2)$ & $60.19(15)^{* * *}$ \\
\hline $\mathrm{Zn}\left(\mu \mathrm{g} \cdot \mathrm{g} \mathrm{DM}^{-1}\right)$ & 353.43 & $41.49(12)$ & $9.54(3) * * *$ \\
\hline
\end{tabular}

\subsection{Effects of the Fertilizers on Soil $p H$ and Soluble $M n$ and $P$}

The application of ABGR caused a $\mathrm{pH}$ reduction of approximately 0.1 units in both fertilization doses in relation to the initial soil pH (Figure 1A). A similar effect was observed with mineral fertilization. The NPK treatments and ABGR treatments were in the range of 6.5 at the same soil pH level. Significant increases were found in the BGR treatments in relation to the initial soil $\mathrm{pH}$. The highest $\mathrm{pH}$ increase was shown in $\mathrm{BGR}_{400}$, which was 0.14 units higher than the initial soil $\mathrm{pH}$ and 0.24 higher than $\mathrm{ABGR}_{400}$. Throughout the experiment, the $\mathrm{pH}$ of the $\mathrm{NK}$ treatment was by far the lowest at 6.2, which corresponds to a reduction of 0.4 units compared with the initial soil $\mathrm{pH}$.

At the end of the experiment, it was shown that $\mathrm{BGR}_{400}$ and $\mathrm{BGR}_{200}$ in particular led to a considerable decrease in the soluble Mn content of the soil (Figure 1B). BGR 400 had the lowest concentration with $0.6 \mathrm{mg} \cdot \mathrm{kg}$ soil ${ }^{-1}$, followed by $\mathrm{BGR}_{200}$ with $0.87 \mathrm{mg} \cdot \mathrm{kg}$ soil ${ }^{-1}$. Fertilization with ABGR increased the soluble soil $\mathrm{Mn}$ to $1.5 \mathrm{mg} \cdot \mathrm{kg}$ soil ${ }^{-1}$ in $\mathrm{ABGR}_{200}$ and $1.9 \mathrm{mg} \cdot \mathrm{kg}$ soil $^{-1}$ in $\mathrm{ABGR}_{400}$. However, the soluble soil Mn of $\mathrm{ABGR}_{200}$ was significantly reduced by $0.69 \mathrm{mg} \cdot \mathrm{kg}$ soil ${ }^{-1}$ compared with $\mathrm{NPK}_{200}$ and by $0.67 \mathrm{mg} \cdot \mathrm{kg}$ soil ${ }^{-1}$ compared with $\mathrm{NPK}_{400}$.

Post harvest, the soluble P concentration in the soil of the NK treatment was $0.88 \mathrm{mg} \cdot \mathrm{kg} \mathrm{soil}{ }^{-1}$, and significantly lower than all treatments fertilized with $\mathrm{P}$, with the exception of $\mathrm{NPK}_{200}$ (Figure 1C). In both fertilizer rates, the P concentration of the acidified treatments was higher than in the mineral-fertilized treatments. However, whereas it was only weakly significant $(p=0.05)$, it showed a clear trend in each case. Acidification only caused a significant increase in the soluble $\mathrm{P}$ fraction in $\mathrm{ABGR}_{400}$ compared with the nonacidified $\mathrm{BGR}_{400}$. 


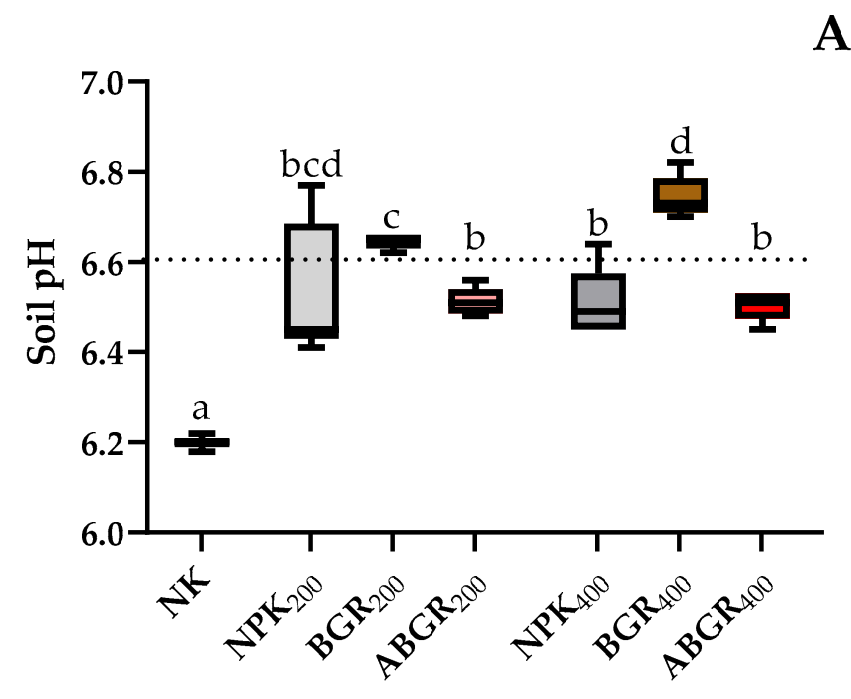

A

B

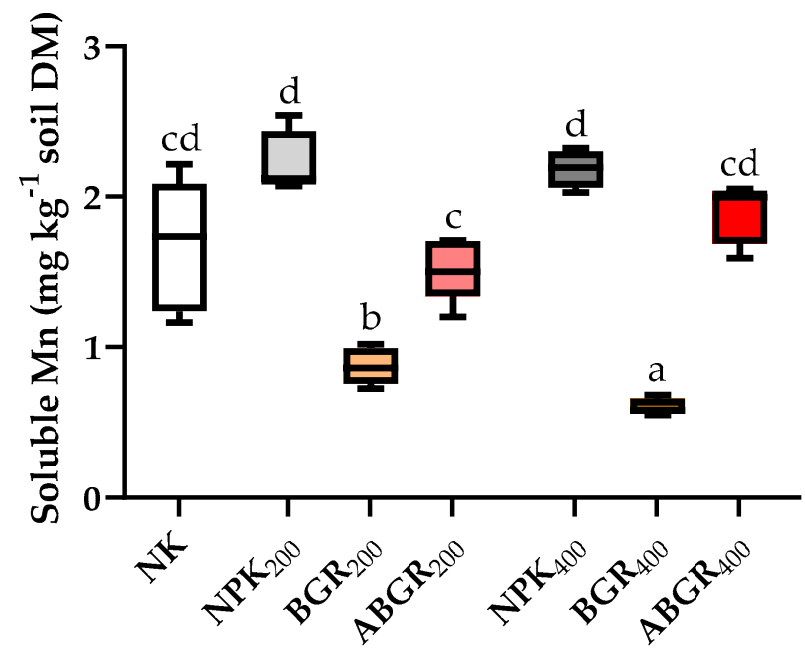

C

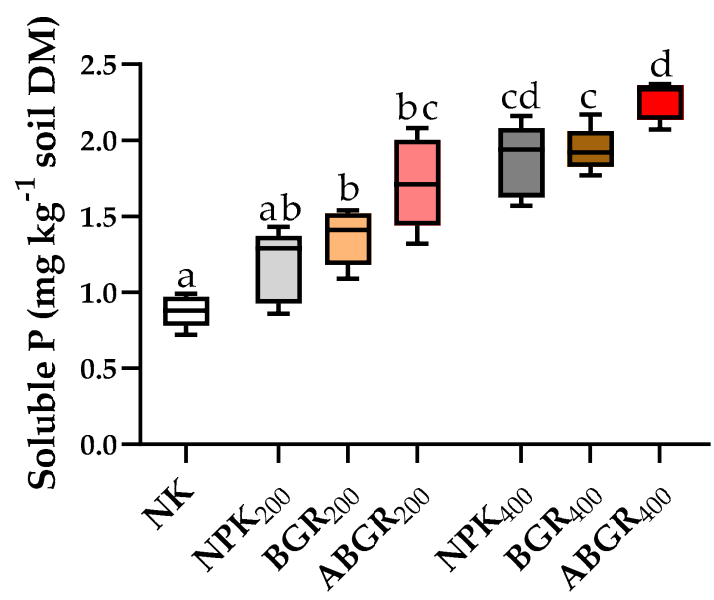

Figure 1. (A) Soil $\mathrm{pH}\left(\mathrm{CaCl}_{2}\right)$ at the end of the experiment. The dashed line corresponds to the initial soil pH. (B) Soluble Mn. (C) Soluble P. For treatment abbreviations, see Table 1. Different letters above the box plots indicate significant differences $(p \leq 0.05)$ between treatments. 


\subsection{Plant Biomass}

Eight weeks after sowing, the biomass values of all P-receiving treatments were significantly higher than those of the NK treatment (Figure 2). In addition, the DM value of $\mathrm{ABGR}_{200}$ was significantly higher than that of $\mathrm{NPK}_{200}$ and $\mathrm{BGR}_{200}$. Fertilization with $\mathrm{ABGR}_{200}$ resulted in a DM value that was $5 \mathrm{~g}$ higher than that of $\mathrm{BGR}_{200}$. The same pattern was also found in maize plants that were fertilized with $400 \mathrm{mg} \mathrm{P} \cdot \mathrm{pot}^{-1}$. The DM value of $A B G R_{400}$ was $28 \mathrm{~g} \cdot$ pot $^{-1}$ and was significantly higher than the DM values for other treatments.

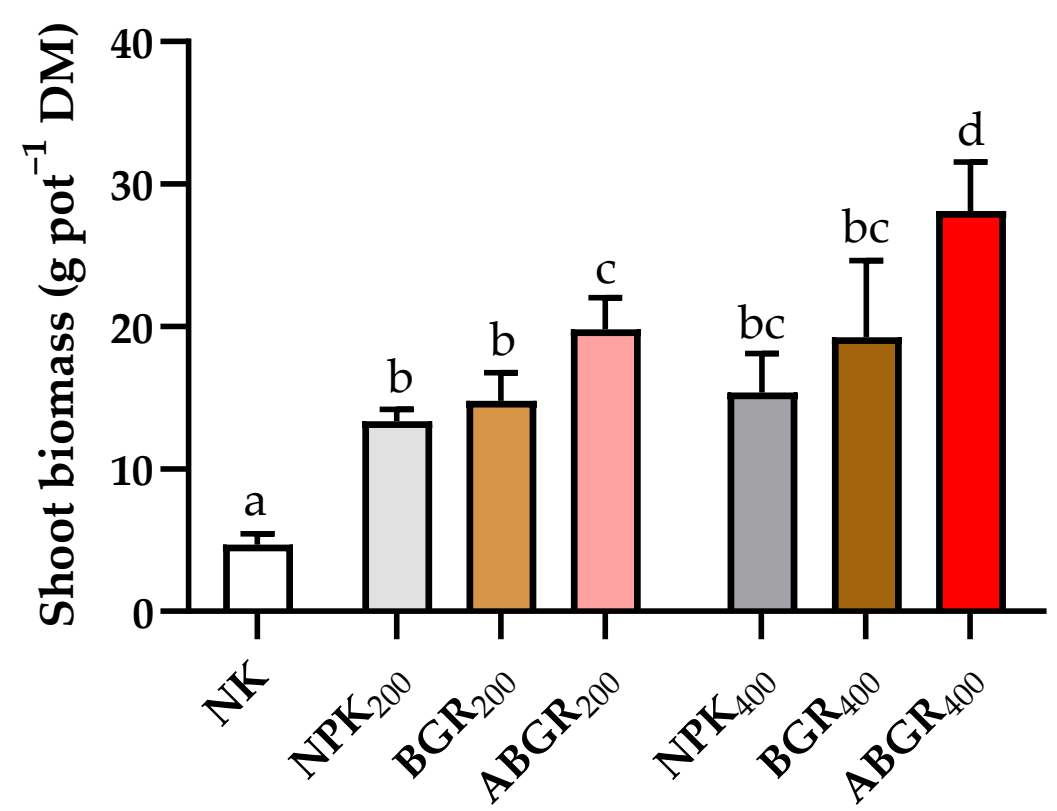

Figure 2. Shoot biomass of maize plants 8 weeks after germination. Values are means $(n=5) \pm$ SD (bars). Different letters above the bars indicate significant differences $(p \leq 0.05)$ between treatments. For treatment abbreviations, see Table 1.

\subsection{Maize Tissue Nutrient Concentrations}

Maize plants that were fertilized with $\mathrm{BGR}_{400}$ and $\mathrm{ABGR}_{400}$ had significantly lower $\mathrm{N}$ concentrations than those fertilized with $\mathrm{NK}, \mathrm{NPK}_{200}$, and NPK 400 (Figure $3 \mathrm{~A}$ ). The $\mathrm{P}$ concentration was influenced neither by mineral fertilization $\left(\mathrm{NPK}_{200}, \mathrm{NPK}_{400}\right)$ nor by BGR or ABGR fertilization (Figure 3B). All plants fertilized with $\mathrm{P}$ had a similar P concentration level to that of NK $\left(2 \mathrm{mg} \cdot \mathrm{g}^{-1}\right)$. The P concentration was significantly higher than with $\mathrm{NPK}_{200}$ in the ABGR 200 treatment only. Fertilization with ABGR had no significant effect on $\mathrm{K}$ and $\mathrm{S}$ concentrations of maize tissue (data not shown). 

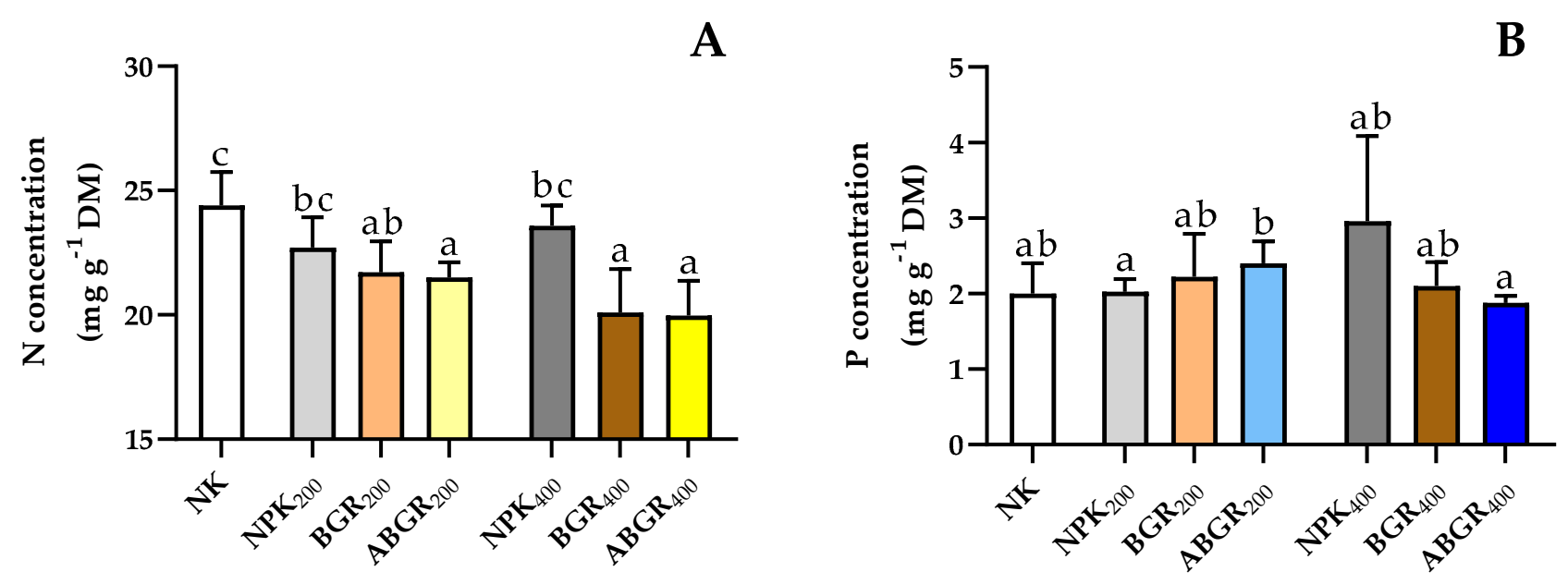

C
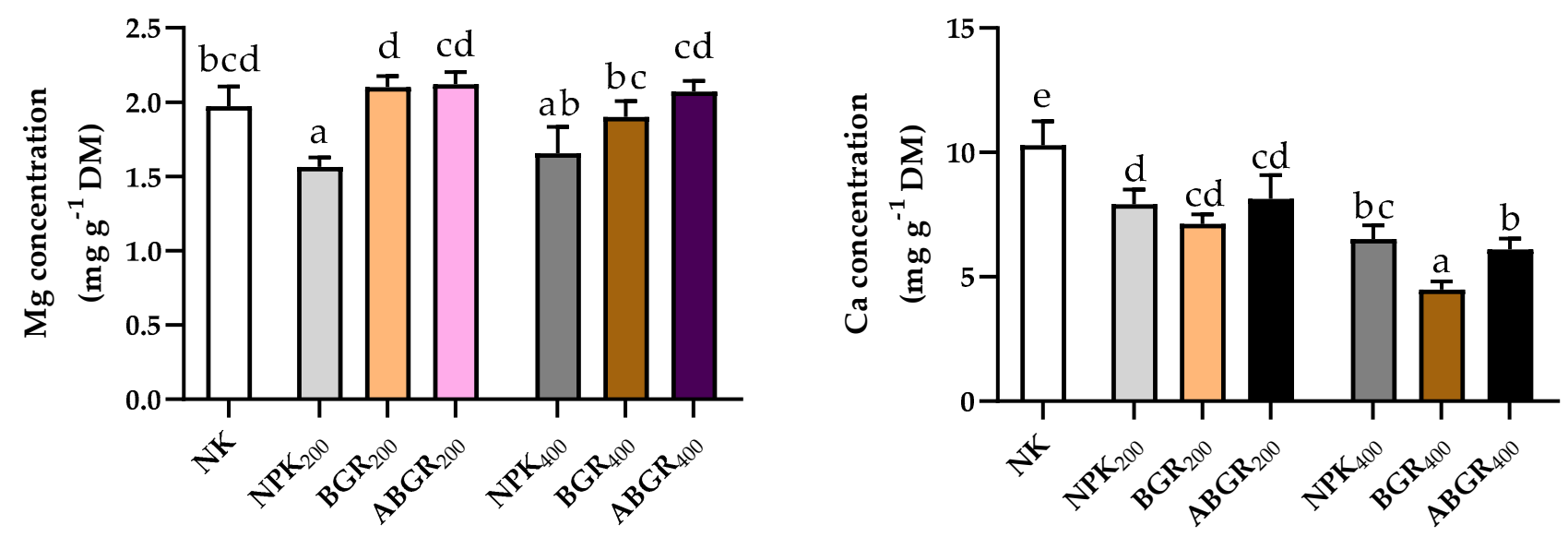

E

$\mathbf{F}$
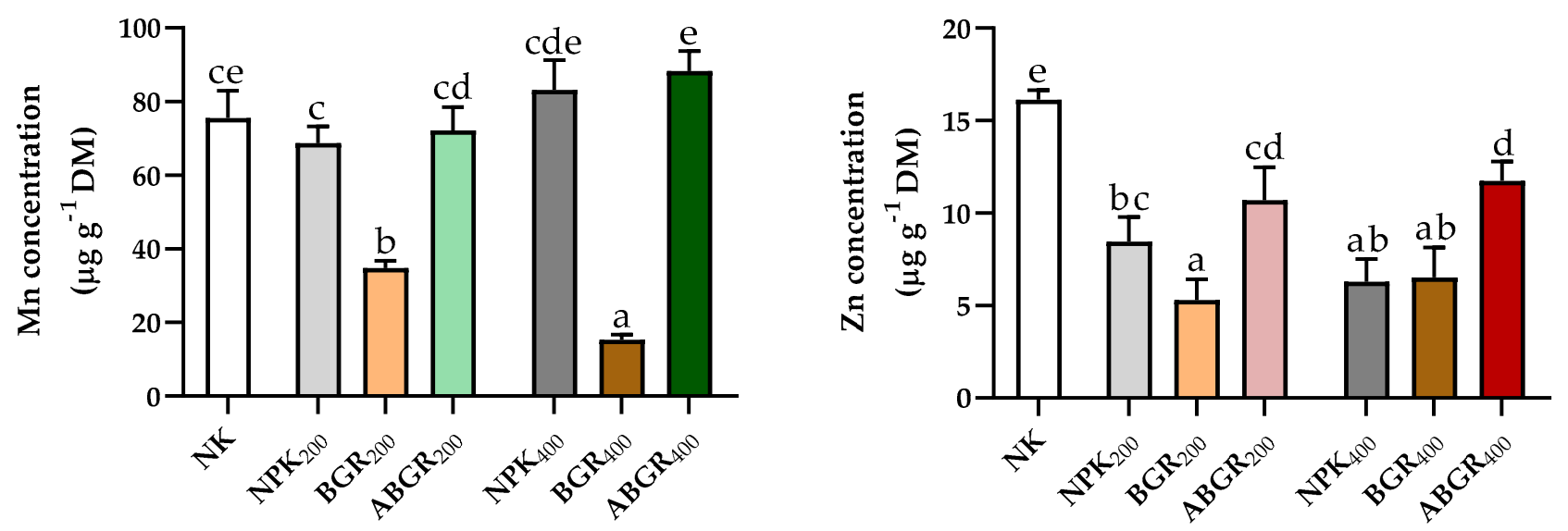

Figure 3. Concentrations of (A) $\mathrm{N},(\mathbf{B}) \mathrm{P},(\mathbf{C}) \mathrm{Mg}$, (D) Ca, (E) Mn, and (F) $\mathrm{Zn}$ of 8 week old maize shoots. Values are the means $(n=5) \pm \mathrm{SD}$ (bars). For treatment abbreviations, see Table 1 . Different letters above the bars indicate significant differences $(p \leq 0.05)$ between treatments.

The $\mathrm{NPK}_{200}$ treatment had the lowest $\mathrm{Mg}$ concentration at $1.6 \mathrm{mg} \cdot \mathrm{g}^{-1}$ (Figure 3C). In the BGR treatments, the acidification had no significant effect on the $\mathrm{Mg}$ concentration of the maize plants. However, the acidification of the BGR resulted in a significantly higher $\mathrm{Mg}$ 
concentration in both fertilization stages compared with the NPK treatments. Maize plants grown in the control (NK) treatment had a Ca concentration of $10.3 \mathrm{mg} \cdot \mathrm{g}^{-1} \mathrm{DM}$, which was significantly higher than those of all other treatments (Figure 3D). Fertilization with $200 \mathrm{mg}$ $P$ reduced Ca concentration regardless of whether the fertilization was $\mathrm{NPK}_{200}, \mathrm{BGR}_{200}$, or $\mathrm{ABGR}_{200}$. The $\mathrm{Ca}$ concentrations of $\mathrm{BGR}_{400}$ and $\mathrm{ABGR}_{400}$ were significantly reduced compared with those of $\mathrm{BGR}_{200}$ and $\mathrm{ABGR}_{200}$. The $\mathrm{BGR}_{400}$ treatment had the lowest $\mathrm{Ca}$ concentration at $4.5 \mathrm{mg} \cdot \mathrm{g}^{-1} \mathrm{DM}$, which was less than half that of the NK treatment.

Fertilization with BGR had the highest impact on the Mn concentration of maize tissues (Figure 3E); while the Mn concentration in the NK and $\mathrm{NPK}_{200}$ treatments was around $70 \mu \mathrm{g} \cdot \mathrm{g}^{-1} \mathrm{DM}$, it was only $35 \mu \mathrm{g} \cdot \mathrm{g}^{-1}$ in the $\mathrm{BGR}_{200}$ treatment. The $\mathrm{ABGR}_{200}$ treatment had an Mn concentration of $72 \mu \mathrm{g} \cdot \mathrm{g}^{-1}$, which was similar to the Mn concentrations of NK and $\mathrm{NPK}_{200}$. The Mn concentration of $\mathrm{BGR}_{400}$ was $15 \mu \mathrm{g} \cdot \mathrm{g}^{-1}$, less than half that of $\mathrm{BGR}_{200}$ and significantly lower than that of all other treatments. Maize plants fertilized with $\mathrm{ABGR}_{400}$ had an Mn concentration of $88 \mu \mathrm{g} \cdot \mathrm{g}^{-1}$, which was significantly higher than that of all other treatments except NK and $\mathrm{NPK}_{400}$.

Significant differences in the $\mathrm{Zn}$ concentration of maize tissue were also detected among treatments (Figure 3F). The Zn concentration of NK was $16 \mu \mathrm{g} \cdot \mathrm{g}^{-1}$, which was significantly higher than that of all other treatments. In contrast, the lowest $\mathrm{Zn}$ concentrations were observed in $\mathrm{BGR}_{200}\left(5.3 \mu \mathrm{g} \cdot \mathrm{g}^{-1}\right)$ and $\mathrm{BGR}_{400}\left(6.5 \mu \mathrm{g} \cdot \mathrm{g}^{-1}\right)$. Acidification of BGR led to an increased $\mathrm{Zn}$ concentration. Zinc concentrations of $\mathrm{ABGR}_{200}$ and $\mathrm{ABGR}_{400}$ were at a similar level, with values of 10.7 , and $11.7 \mu \mathrm{g} \cdot \mathrm{g}^{-1}$, respectively. This corresponds to a doubling of the $\mathrm{Zn}$ concentration compared with $\mathrm{BGR}_{200}$ and $\mathrm{BGR}_{400}$.

\subsection{Nutrient Uptake and Relative Effectiveness of P Fertilization}

Acidification increased $\mathrm{N}$ uptake at both fertilizer levels (Table 3). In $\mathrm{ABGR}_{200}, \mathrm{~N}$ uptake was increased by $93 \mathrm{mg} \mathrm{N}$ compared with $\mathrm{BGR}_{200}$; however, this was not statistically significant $(p=0.07)$. In $\mathrm{ABGR}_{400}$, acidification led to a significant increase of $183 \mathrm{mg} \mathrm{N}$ compared with $\mathrm{BGR}_{400}$. Compared with NPK, the $\mathrm{N}$ uptake was significantly increased by acidification in both $\mathrm{ABGR}_{200}$ and $\mathrm{ABGR}_{400}$.

Table 3. Nutrient uptake of selected elements of 8 week old maize shoots $(n=5)$ and ANOVA results for each element. Different letters in a column indicate significant differences $(p \leq 0.05)$ between treatments. For treatment abbreviations, see Table 1.

\begin{tabular}{|c|c|c|c|c|c|c|c|c|c|}
\hline \multirow{3}{*}{ Treatment } & \multicolumn{5}{|c|}{ Macronutrient Uptake } & \multirow[b]{2}{*}{$\mathrm{Mg}$} & \multicolumn{3}{|c|}{ Micronutrient Uptake } \\
\hline & $\mathbf{N}$ & $\mathbf{P}$ & $\mathbf{K}$ & Ca & S & & Mn & $\mathrm{Fe}$ & Zn \\
\hline & \multicolumn{6}{|c|}{$\left(\mathrm{mg} \cdot \mathrm{pot}^{-1}\right)$} & \multicolumn{3}{|c|}{$\left(\mu \mathrm{g} \cdot \operatorname{pot}^{-1}\right)$} \\
\hline NK & $113.8 \mathrm{a}$ & $8.3 \mathrm{a}$ & $282.2 \mathrm{a}$ & $48.4 \mathrm{a}$ & $7.8 \mathrm{a}$ & $8.9 \mathrm{a}$ & $334.9 \mathrm{a}$ & $286.5 \mathrm{a}$ & $69.8 \mathrm{a}$ \\
\hline $\mathrm{NPK}_{200}$ & $269.7 \mathrm{~b}$ & $26.9 \mathrm{~b}$ & $788.7 \mathrm{~b}$ & $105.6 \mathrm{bc}$ & $18.7 \mathrm{~b}$ & $22.6 \mathrm{~b}$ & $906.1 \mathrm{c}$ & $572.5 \mathrm{ab}$ & $123.6 \mathrm{~b}$ \\
\hline $\mathrm{BGR}_{200}$ & $320.5 \mathrm{bc}$ & $29.6 \mathrm{bc}$ & $973.8 \mathrm{bc}$ & $105.3 \mathrm{bc}$ & $24.6 \mathrm{bc}$ & $30.6 \mathrm{bc}$ & $495.6 \mathrm{~b}$ & $1108.9 \mathrm{c}$ & $74.4 \mathrm{a}$ \\
\hline $\mathrm{ABGR}_{200}$ & $413.3 \mathrm{~cd}$ & $47.8 \mathrm{~d}$ & 1042 bc & $146.3 \mathrm{~cd}$ & $31.8 \mathrm{c}$ & $35.9 \mathrm{c}$ & $1311.8 \mathrm{~cd}$ & $1100.8 \mathrm{bcd}$ & $209.8 \mathrm{c}$ \\
\hline $\mathrm{NPK}_{400}$ & $370.0 \mathrm{bc}$ & $38.5 \mathrm{bcd}$ & $846.4 \mathrm{~b}$ & $115.7 \mathrm{C}$ & $28.6 \mathrm{c}$ & $28.5 \mathrm{bc}$ & $1338.3 \mathrm{~d}$ & $987.3 \mathrm{c}$ & $94.3 \mathrm{ab}$ \\
\hline $\mathrm{BGR}_{400}$ & $380.2 \mathrm{bc}$ & $42.5 \mathrm{~cd}$ & $1018.5 \mathrm{bc}$ & $85.3 \mathrm{~b}$ & $29.0 \mathrm{bc}$ & $36.4 \mathrm{bc}$ & $262.8 \mathrm{a}$ & $1146.7 \mathrm{bcd}$ & $105.9 \mathrm{ab}$ \\
\hline $\mathrm{ABGR}_{400}$ & $563.5 \mathrm{~d}$ & $52.4 \mathrm{~d}$ & $1526.7 \mathrm{c}$ & $172.4 \mathrm{~d}$ & $45.0 \mathrm{~d}$ & $58.4 \mathrm{~d}$ & $2625.9 \mathrm{e}$ & $1729.2 \mathrm{~d}$ & $312.1 \mathrm{~d}$ \\
\hline
\end{tabular}

The RPE (\%) P uptake values of BGR and ABGR were then compared with the NPK treatments. The RPE of the fertilizer treatments decreased in the following order: $\mathrm{ABGR}_{200}$ $(212 \%)>\mathrm{ABGR}_{400}(146 \%)>\mathrm{BGR}_{400}(122 \%)>\mathrm{BGR}_{200}(115 \%)$. The P uptake of $\mathrm{ABGR}_{200}$ was significantly higher than that of $\mathrm{NK}, \mathrm{NPK}_{200}$, and $\mathrm{BGR}_{200}$ and reached the same level as the $400 \mathrm{mg}$ P treatments.

Fertilization with P had increasing effects on Ca uptake. The Ca uptake of NK was significantly lower than that of all other treatments, at $48 \mathrm{mg} \cdot \mathrm{pot}^{-1}$ (Table 3). The Ca uptake values were highest in the ABGR treatments. The increase was especially evident for $\mathrm{ABGR}_{400}$, where Ca uptake was $172 \mathrm{mg} \cdot \mathrm{pot}^{-1}$, twice as high as that of $\mathrm{BGR}_{400}$. In 
addition, Ca uptake was increased in $\mathrm{ABGR}_{200}$ compared with $\mathrm{BGR}_{200}$, but this increase was not significant $(p=0.06)$.

The Mg uptake was significantly lower in the NK than that of all other treatments, at $8.9 \mathrm{mg} \cdot$ pot $^{-1}$ (Table 3). The $\mathrm{Mg}$ uptake of the $A B G R_{200}$ treatment $\left(35.9 \mathrm{mg} \cdot\right.$ pot $^{-1}$ ) was significantly higher than that of $\mathrm{NPK}_{200}\left(22.6 \mathrm{mg} \cdot \mathrm{pot}^{-1}\right)$. A similar increasing effect was also observed in $\mathrm{ABGR}_{400}$, where the $\mathrm{Mg}$ uptake was $58.4 \mathrm{mg} \cdot \mathrm{pot}^{-1}$ compared with $^{-1}$ $29 \mathrm{mg} \cdot \mathrm{pot}^{-1}$ for $\mathrm{NPK}_{400}$. The Mg uptake was also significantly lower in $\mathrm{BGR}_{400}$ compared with $\mathrm{ABGR}_{400}$.

When maize was fertilized with $\mathrm{BGR}_{400}$, Mn uptake was $72 \mu \mathrm{g} \cdot \operatorname{pot}^{-1}$ lower than that of NK and $233 \mu \mathrm{g} \cdot$ pot $^{-1}$ lower than that of BGR 200 (Table 3). The Mn uptake in $\mathrm{ABGR}_{200}$ was $406 \mu \mathrm{g} \cdot$ pot $^{-1}$ higher than that of $\mathrm{NPK}_{200}$ and $812 \mu \mathrm{g} \cdot$ pot $^{-1}$ higher than that of $\mathrm{BGR}_{200}$. These effects were even more pronounced in the $400 \mathrm{mg}$ P fertilizer treatments. The Mn uptake of $\mathrm{ABGR}_{400}$ was almost doubled $\left(+1288 \mu \mathrm{g} \cdot \mathrm{pot}^{-1}\right)$ compared with $\mathrm{NPK}_{400}$ and 10 times higher than that of $\mathrm{BGR}_{400}\left(+2363 \mu \mathrm{g} \cdot \mathrm{pot}^{-1}\right)$. In addition, the Mn uptake of $\mathrm{ABGR}_{400}$ was almost double that of $\mathrm{ABGR}_{200}$.

The values of $\mathrm{Zn}$ uptake were almost the same among the NK, BGR 200 , and BGR 400 treatments (Table 3). Acidification led to significant increases in $\mathrm{Zn}$ uptake in $\mathrm{ABGR}_{200}$ and $\mathrm{ABGR}_{400}$. The $\mathrm{Zn}$ uptake was $86 \mu \mathrm{g} \cdot$ pot $^{-1}$ higher in $\mathrm{ABGR}_{200}$ than that of $\mathrm{NPK}_{200}$ and $135 \mu \mathrm{g} \cdot$ pot $^{-1}$ higher than that of BGR 200 . The $\mathrm{Zn}$ uptake of $\mathrm{ABGR}_{400}$ was $312 \mu \mathrm{g} \cdot \mathrm{pot}^{-1}$, three times higher than the values observed for $\mathrm{NPK}_{400}$ and $\mathrm{BGR}_{400}$.

\section{Discussion}

\subsection{Effects of Acidification on BGR Composition}

Acidification of BGR increased $\mathrm{H}_{2} \mathrm{O}$-soluble $\mathrm{P}$ and $\mathrm{Ca}$, suggesting that minerals that are present under alkaline conditions (e.g., brushite and hydroxylapatite [14]) were decomposed as a result of lowering the $\mathrm{pH}$ to 5.5. We observed an increase of $\mathrm{H}_{2} \mathrm{O}$-soluble P from $15 \%$ to $44 \%$ of TP. These results correspond well with Regueiro et al. [9], who found an $\mathrm{H}_{2} \mathrm{O}$-soluble $\mathrm{P}$ content of $36 \%$ in acidified pig slurry, while the dissolved $\mathrm{P}$ in the untreated slurry ( $\mathrm{pH}$ 7.4) was below the detection limit. Very similar results were obtained by Pedersen et al. [12] with acidified cattle slurry. In their study, the $\mathrm{H}_{2} \mathrm{O}$-soluble $\mathrm{P}$ in raw slurry at pH 6.5 (32\%) increased by acidification to $\mathrm{pH} 5.5$ to $69 \%$.

Our results confirm the link between $\mathrm{P}$ and $\mathrm{Mg}$. It is known that the mineral struvite $\left(\mathrm{MgNH}_{4} \mathrm{PO}_{4} \cdot 6 \mathrm{H}_{2} \mathrm{O}\right)$ precipitates in $\mathrm{BGR}$ at $\mathrm{pH}$ values between 8 and 9 [32], resulting in a decrease in direct plant availability of $\mathrm{P}$. In turn, as the $\mathrm{pH}$ value decreases, these minerals dissolve again. This was confirmed by the increased $\mathrm{H}_{2} \mathrm{O}$-solubilities of $\mathrm{Mg}$, which amounted to $37 \%$ for ABGR and only $7 \%$ for BGR. Similar effects on soluble $\mathrm{P}, \mathrm{Mg}$, and $\mathrm{Ca}$ in acidified pig slurry were also demonstrated by Hjorth et al. [10]. The results of our study confirmed our first hypothesis. However, it is important to note that the increased P solubility of ABGR is only a snapshot. Since the $\mathrm{pH}$ increases again during storage, the solubility would then decrease once more. Regueiro et al. [33] examined the impact of acidification on slurry composition of pig and dairy slurry and reported that $\mathrm{pH}$ and $\mathrm{P}$ solubility returned to the level of untreated slurry after less than 20 days. It can be assumed that this effect can be transferred to ABGR.

Our second hypothesis can only partially be confirmed. While the proportions of $\mathrm{H}_{2} \mathrm{O}$ soluble $\mathrm{Ca}, \mathrm{Mg}$, and $\mathrm{Mn}$ significantly increased, those of dissolved $\mathrm{Cu}, \mathrm{Zn}$, and Fe were reduced. Hjorth et al. [10] showed that the particle size of pig slurry increased as result of acidification. Both $\mathrm{Cu}$ and $\mathrm{Zn}$ are particularly well known for their high affinity to bind to particles [34]. It can, therefore, be assumed that the reduced solubility of $\mathrm{Cu}$ and $\mathrm{Zn}$ was due to an accumulation on bigger particles, which were then removed from the liquid phase. Comparable effects were also described by Cocolo et al. [35] in acidified pig slurry. However, this effect appears to be much more pronounced with BGR, because the particle size is already increased during the anaerobic digestion [36]. 


\subsection{Acid Demand and Effects of the Fertilizers on Soil}

Compared with studies on acidified pig or cattle slurry, the required acid amount was highest in the present investigation at $17.3 \mathrm{~mL}$ of $\mathrm{H}_{2} \mathrm{SO}_{4}$ per $\mathrm{kg}$ BGR. This is because BGR has a much higher initial $\mathrm{pH}$ and puffer capacity than raw slurries. In a study investigating acidification of pig and cattle slurry, Stevens et al. [16] reported a significant positive linear relationship between $\mathrm{NH}_{4}{ }^{+}$content and acid demand, and it is well known that the $\mathrm{NH}_{4}{ }^{+}$ content increases under anaerobic digestion [13]. Sigurnjak et al. [37] reported that $14.7 \mathrm{~mL}$ of $\mathrm{H}_{2} \mathrm{SO}_{4}$ was needed per $\mathrm{L}$ of codigested waste from the food industry. Hjorth et al. [10] used $10.6 \mathrm{~mL}$ of $\mathrm{H}_{2} \mathrm{SO}_{4}$ per $\mathrm{kg}$ pig slurry $\left(9.5 \mathrm{~L} / \mathrm{m}^{3}\right.$ (recalculated)) for acidification from $\mathrm{pH} 7.1$ to 5.3, and Pedersen et al. [12] reported that $1.7 \mathrm{~mL}$ of $\mathrm{H}_{2} \mathrm{SO}_{4}$ was needed per $\mathrm{kg}$ cattle slurry in their experiment, which is only $10 \%$ of the acid demand of our experiment.

Our third hypothesis was that the application of ABGR will decrease soil $\mathrm{pH}$. Our results confirmed this hypothesis. The application of ABGR decreased soil $\mathrm{pH}$ to the same extent as NPK, whereas BGR caused increased soil $\mathrm{pH}$ compared with the initial value (Figure 1A). The $\mathrm{pH}$-increasing effect of BGR reflected the results of Bachmann et al. [38], who also found an increased soil $\mathrm{pH}$ after application of codigested dairy slurry. Chen et al. [39] demonstrated that applied BGR acts as a buffer in the soil, thereby neutralizing the soil $\mathrm{pH}$ depending on the initial value. In contrast, Prays and Kaupenjohann [40] showed that soil $\mathrm{pH}$ decreased even under fertilization with alkaline BGR. Sigurnjak et al. [37] showed that the application of a BGR with $\mathrm{pH} 8.1$ to a soil with $\mathrm{pH}$ of 4.9 had no $\mathrm{pH}$-increasing effect. This differs from our findings, but Sigurnjak et al. [37] were also able to show a pH reduction by ABGR; however, acidified pig slurry had no effect on soil $\mathrm{pH}$ in their study. Berg et al. [41] also showed that the application of pig slurry acidified to $\mathrm{pH} 4.5$ and cattle slurry acidified to $\mathrm{pH} 5$ had no effect on soil $\mathrm{pH}$. In our experiment, we explained the $\mathrm{pH}$-lowering effect of ABGR on soil as the sum of the direct impact of the applied sulfate and the increased $\mathrm{NH}_{4}{ }^{+}$supplied to the soil. Regueiro et al. [33] showed that, through acidification with $\mathrm{H}_{2} \mathrm{SO}_{4}$, the $\mathrm{NH}_{4}{ }^{+}$concentrations of both cattle slurry and pig slurry were still significantly higher than those in the raw slurry after 60 days. Higher soil $\mathrm{NH}_{4}{ }^{+}$concentrations in turn lead to two proton-releasing processes in soils: (1) nitrification and (2) proton extrusion of roots in exchange for $\mathrm{NH}_{4}^{+}$ uptake. It should be noted, however, that the soil in our experiment was loamy sand with high initial $\mathrm{pH}$ of 6.6. Another soil with a high buffer capacity is likely to have reacted differently to fertilization. It should also be considered that this was a pot trial conducted only over the first 8 weeks of maize development. How these results can be transferred to a field situation over an entire growing season is, therefore, difficult to transfer.

Fertilization with BGR led to an increase in soil $\mathrm{pH}$ and, thus, to a reduction in the solubility of soil $\mathrm{Mn}$. In northern Germany, the arable soils normally contain considerably higher $\mathrm{Mn}$ than the crop demand; however, unfortunately, most of the Mn is not in a plant-available form. The amount of Mn available to plants is controlled by, among other things, the acidity and redox potential of the soil, which has long been known [42]. It can be surmised that, with decreasing $\mathrm{pH}$ value, the amount of available Mn increases. However, in our case, the treatment with the significantly lowest soil $\mathrm{pH}(\mathrm{NK})$ did not have the highest plant-available quantity of $\mathrm{Mn}$. This can be explained, on the one hand, by the fact that the organically fertilized treatments also contain $\mathrm{Mn}$ (5 mg Mn for BGR/ABGR 200 and $10 \mathrm{mg}$ for $\mathrm{BGR} / \mathrm{ABGR}_{400}$ ). On the other hand, Mn could not be classified as a yieldlimiting factor in this experiment, as the available soil Mn concentrations in both NPK treatments were at the same level or even higher than in the ABGR treatments, although NPK did not receive additional Mn. However, the NK treatment received the highest mineral $\mathrm{NH}_{4} \mathrm{SO}_{4}$ fertilization, and it is known that this fertilizer increases the availability of $\mathrm{Mn}$ in the soil [43].

\subsection{Effects on Plant Growth, Nutrient Concentration, and Nutrient Uptake}

Our results show that BGR acidification improved the nutrient supply for maize plants during the early growth phases, which generates a higher biomass. This is particularly 
important because, due to a high nutrient requirement and a relatively weak developed root system, maize plants place the highest demands on nutrient supply during the early stages of their development. This is especially important for P, because P moves in the soil via diffusion to the plant roots [44]. An increase in the root development of the plants increases the $\mathrm{P}$ uptake. Therefore, at the beginning of $\mathrm{P}$ deficiency, root growth is initially increased until further P deficiency decreases both root and shoot growth [45]. In our study, we generated comparable DM biomass with $200 \mathrm{mg} P$ from ABGR and with $400 \mathrm{mg} P$ from untreated BGR. Acidification had no negative effects in the growth of young maize plants. This outcome is contrary to that of Sigurnjak et al. [37], who found decreased FM yield of lettuce (Lactuca sativa L.) after fertilization with ABGR.

A dilution effect can clearly be seen in the $\mathrm{N}$ concentrations in plant tissue. Our results show that the plants with the highest biomass growth also had the lowest $\mathrm{N}$ concentrations, although $\mathrm{N}$ was conserved in the soil as a result of the acidification. However, acidification increased $\mathrm{N}$ uptake at both fertilizer levels. A very similar effect, although not as pronounced as that for $\mathrm{N}$, was observed for $\mathrm{P}$ concentration. Although $\mathrm{P}$ was much more soluble in ABGR as a result of acidification, and the soluble $P$ in the acidified treatments was also increased in the soil at the end of the experiment, no increased P concentrations were found in the maize plant tissues. These results are consistent with those of Pedersen et al. [12], who found no differences in P concentration in maize plants at the seven-leaf stage fertilized with cattle slurry or acidified cattle slurry.

Since the $\mathrm{Mg}$ concentrations and $\mathrm{Mg}$ uptake were both significantly higher at both acidified application rates than in NPK fertilization, it can be assumed that there is an Mg fertilization effect of struvite in ABGR treatments. Fertilization with struvite can increase the $\mathrm{Mg}$ uptake of crops [46]. The most striking result to emerge from the current study is that the Mn concentration and Mn uptake of maize fertilized with BGR dramatically decreased, and the Mn uptake of $\mathrm{BGR}_{400}$ was even lower than that of the unfertilized control plants. This effect was eliminated efficiently by the acidification of BGR. For maize, Mn supply tends to play a minor role; however, for wheat and barley, for example, improving the availability of Mn by acidifying BGR or slurry will be an enormous advantage. This will be a fruitful area for further research, especially under field conditions in northern Europe, where Mn deficiency could be a yield-limiting problem.

The very low $\mathrm{Ca}$ concentrations and low Ca uptake of the plants can be explained by the fact that BGR treatments were fertilized with a considerably lower proportion of soluble Ca compared with ABGR treatments (Table 2). This is because calcite $\left(\mathrm{CaCO}_{3}\right)$ precipitation occurs in BGR, since carbonates are present in excess as a result of anaerobic digestion, and these precipitation processes are mainly controlled by the $\mathrm{pH}$ value and Ca [17]. Bachmann [23] was also able to show that the Ca uptake of 8 week old maize and amaranth plants fertilized with anaerobic digested cattle slurry was lower than that of NK and NPK on both sandy and loamy soils. However, in her study, the NPK treatment was triple superphosphate, whereby additional Ca was applied, whereas the NPK in our experiment was Ca-free $\left(\mathrm{NH}_{4}\right)_{2} \mathrm{HPO}_{4}$. It can be assumed, however, that acute Ca deficiency in the BGR treatments was not the cause of the lower biomass production, as the typical Ca deficiency symptoms for maize ("buggy-whipping") were not noticeable.

The results showed that the $\mathrm{Zn}$ concentration of ABGR plants at both application rates was significantly higher than the Zn concentration of BGR. On the one hand, this is no surprise, because $\mathrm{Zn}$, like most micronutrients, is better available to plants at low soil $\mathrm{pH}$. On the other hand, $\mathrm{Zn}$ was one of the micronutrients whose solubility decreased when $\mathrm{H}_{2} \mathrm{SO}_{4}$ was added to the BGR. It can, therefore, be assumed that the $\mathrm{Zn}$ absorbed by the plants is more likely to come from the soil than from the applied BGR. This is also supported by the fact that the Zn concentrations were significantly higher in NK than in all treatments. Sigurnjak et al. [37] observed similar results with acidified pig slurry and ABGR, which led to higher $\mathrm{Zn}$ concentrations in lettuce compared with those in lettuce grown under untreated slurry or BGR. 
As the $S$ concentration in the maize plants was the same for all treatments (data not shown), it can be assumed that $S$ did not limit the yield in the pot experiment. Although $S$ was applied in excess as a result of acidification, the plants did not engage in overconsumption of S. Furthermore, no negative effect on the plants was observed because of the high application rate of $S$.

It can be assumed that this effect is not solely based on the increased $\mathrm{N}$ efficiency or increased P availability. Thus, because BGR are mixtures of substances and multiple nutrient fertilizers, it is difficult to isolate one single yield-promoting effect. Rather, multiple factors together led to improved plant growth, which confirms our fourth hypothesis.

\section{Conclusions}

In the future, farmers in the EU will be increasingly forced by law to reduce the application of slurry and BGR. For example, in some regions in northern Germany, farmers will have to reduce their average fertilizer requirements by $20 \%$ from 2021 onward. Therefore, techniques have to be identified to generate consistent or increasing yields with reduced fertilizer application rates. According to our results, ABGR is a good starter fertilizer for maize. In both tested fertilization rates, ABGR increased the plant biomass of maize after 8 weeks. Moreover, fertilization with ABGR even exceeded the effect of the tested mineral $P$ fertilizer, which implies that mineral $P$ fertilizer could potentially be replaced by ABGR. This can improve the $\mathrm{P}$ balance of a forage farm. To decrease the $\mathrm{pH}$ of BGR to 5.5, a significantly larger quantity of $\mathrm{H}_{2} \mathrm{SO}_{4}$ is required as for pig or cattle slurry. Although more $\mathrm{H}_{2} \mathrm{SO}_{4}$ was used, no damage to the maize seedlings was observed. However, the $\mathrm{pH}$ of the soil was lowered below its initial value after the application of ABGR, whereas the $\mathrm{pH}$ was not decreased lower than in the mineral $\mathrm{P}$ fertilized treatments. Furthermore, Mn and $\mathrm{Zn}$ nutrition of the maize plants was also significantly increased by ABGR application. In addition to the increasing biomass growth, acidification could also contribute to an improvement in feed quality of maize silage, as demonstrated by the increased $\mathrm{Ca}, \mathrm{Mg}$, and P uptake. Our results also highlight that fertilization with BGR decreased both Mn concentration and Mn uptake by maize, which was prevented by ABGR.

Author Contributions: Conceptualization, visualization, investigation, laboratory work, data collection, data analysis, and writing-original draft, J.T.M.; investigation, B.M.G.; conceptualization, project administration, supervision, and review, K.-H.M. All authors have read and agreed to the published version of the manuscript.

Funding: The project was funded by the Stiftung Schleswig-Holsteinische Landschaft, Kiel.

Acknowledgments: The statistical advice of M. Hasler is gratefully acknowledged. We acknowledge financial support by Land Schleswig-Holstein within the funding program Open Access Publikationsfonds.

Conflicts of Interest: The authors declare no conflict of interest. 


\section{Appendix A}

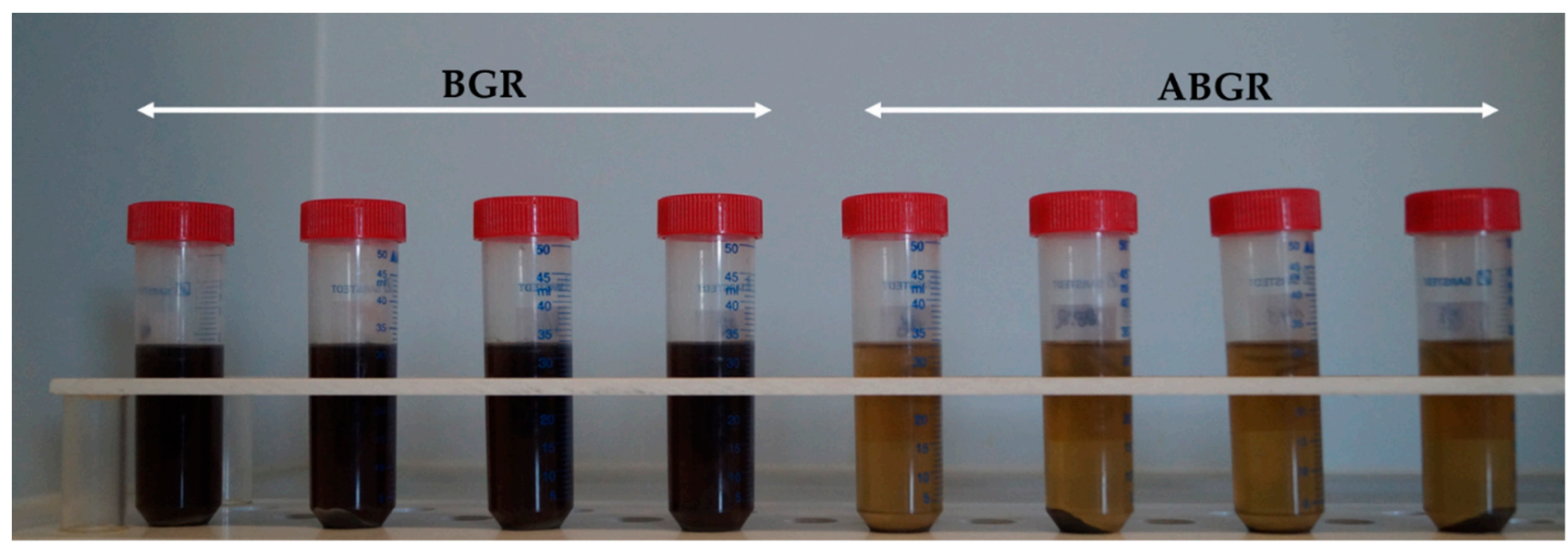

Figure A1. BGR and ABGR after centrifugation before determination of dissolved nutrients.

\section{References}

1. Husted, S.; Jensen, L.S.; Jørgensen, S.S. Reducing ammonia loss from cattle slurry by the use of acidifying additives: The role of the buffer system. J. Sci. Food Agric. 1991, 57, 335-349. [CrossRef]

2. Fangueiro, D.; Hjorth, M.; Gioelli, F. Acidification of animal slurry-A review. J. Environ. Manag. 2015, 149, 46-56. [CrossRef]

3. Ndegwa, P.M.; Hristov, A.N.; Arogo, J.; Sheffield, R.E. A review of ammonia emission mitigation techniques for concentrated animal feeding operations. Biosyst. Eng. 2008, 100, 453-469. [CrossRef]

4. IRECTIVE (EU) 2016/2284 of the European Parliament and of the Council-Of 14 December 2016-On the Reduction of National Emissions of Certain Atmospheric Pollutants, Amending Directive 2003/35/EC and Repealing Directive 2001/81/EC. DIRECTIVE (EU) 2016/2284; European Parliament: Strasbourg, France, 2016.

5. Commission Implementing DECISION (EU) 2017/302 of 15 February 2017 Establishing Best Available Techniques (BAT) Conclusions, under Directive 2010/75/EU of the European Parliament and of the Council, for the Intensive Rearing of Poultry or Pigs. Directive 2010/75/EU; European Parliament: Strasbourg, France, 2017.

6. Eriksen, J.; Sørensen, P.; Elsgaard, L. The fate of sulfate in acidified pig slurry during storage and following application to cropped soil. J. Environ. Qual. 2008, 37, 280-286. [CrossRef]

7. Pedersen, I.F.; Rubæk, G.H.; Nyord, T.; Sørensen, P. Row-injected cattle slurry can replace mineral P starter fertiliser and reduce P surpluses without compromising final yields of silage maize. Eur. J. Agron. 2020, 116, 126057. [CrossRef]

8. Seidel, A.; Pacholski, A.; Nyord, T.; Vestergaard, A.; Pahlmann, I.; Herrmann, A.; Kage, H. Effects of acidification and injection of pasture applied cattle slurry on ammonia losses, $\mathrm{N}_{2} \mathrm{O}$ emissions and crop N uptake. Agric. Ecosyst. Environ. 2017, $247,23-32$. [CrossRef]

9. Regueiro, I.; Coutinho, J.; Balsari, P.; Popovic, O.; Fangueiro, D. Acidification of pig slurry before separation to improve slurry management on farms. Environ. Technol. 2016, 37, 1906-1913. [CrossRef] [PubMed]

10. Hjorth, M.; Cocolo, G.; Jonassen, K.; Abildgaard, L.; Sommer, S.G. Continuous in-house acidification affecting animal slurry composition. Biosyst. Eng. 2015, 132, 56-60. [CrossRef]

11. Fangueiro, D.; Pereira, J.L.S.; Fraga, I.; Surgy, S.; Vasconcelos, E.; Coutinho, J. Band application of acidified slurry as an alternative to slurry injection in a Mediterranean double cropping system: Agronomic effect and gaseous emissions. Agric. Ecosyst. Environ. 2018, 267, 87-99. [CrossRef]

12. Pedersen, I.F.; Rubæk, G.H.; Sørensen, P. Cattle slurry acidification and application method can improve initial phosphorus availability for maize. Plant Soil 2017, 414, 143-158. [CrossRef]

13. Möller, K.; Müller, T. Effects of anaerobic digestion on digestate nutrient availability and crop growth: A review. Eng. Life Sci. 2012, 12, 242-257. [CrossRef]

14. Güngör, K.; Jürgensen, A.; Karthikeyan, K.G. Determination of phosphorus speciation in dairy manure using XRD and XANES spectroscopy. J. Environ. Qual. 2007, 36, 1856-1863. [CrossRef] [PubMed]

15. Muster, T.H.; Douglas, G.B.; Sherman, N.; Seeber, A.; Wright, N.; Güzükara, Y. Towards effective phosphorus recycling from wastewater: Quantity and quality. Chemosphere 2013, 91, 676-684. [CrossRef]

16. Stevens, R.J.; Laughlin, R.J.; Frost, J.P. Effect of acidification with sulphuric acid on the volatilization of ammonia from cow and pig slurries. J. Agric. Sci. 1989, 113, 389-395. [CrossRef]

17. Sommer, S.G.; Husted, S. The chemical buffer system in raw and digested animal slurry. J. Agric. Sci. 1995, 124, 45-53. [CrossRef]

18. Dou, Z.; Toth, J.D.; Galligan, D.T.; Ramberg, C.F.; Ferguson, J.D. Laboratory Procedures for Characterizing Manure Phosphorus. J. Environ. Qual. 2000, 29, 508. [CrossRef] 
19. Murphy, J.; Riley, J.P. A modified single solution method for the determination of phosphate in natural waters. Anal. Chim. Acta 1962, 27, 31-36. [CrossRef]

20. Schüller, H. Die CAL-Methode, eine neue Methode zur Bestimmung des pflanzenverfügbaren Phosphates in Böden. Z. Pflanz. Bodenkde 1969, 123, 48-63. [CrossRef]

21. Blume, H.-P. (Ed.) Handbuch der Bodenuntersuchung. Terminologie, Verfahrensvorschriften und Datenblätter; Physikalische, Chemische, Biologische Untersuchungsverfahren; Gesetzliche Regelwerke; Wiley-VCH, Beuth: Weinheim/Berlin, Germany; Wien, Austria; Zürich, Switzerland, 2000; ISBN 978-3-527-19080-5.

22. Barry, D.A.J.; Miller, M.H. Phosphorus Nutritional Requirement of Maize Seedlings for Maximum Yield. Agron. J. 1989, 81, 95-99. [CrossRef]

23. Bachmann, S. Phosphor-Düngewirkung von Biogasgüllen: Ein Beitrag zur Sicherung Einer Nachhaltigen Bioenergieproduktion. Ph.D. Thesis, University of Rostock, Rostock, Germany, 2012.

24. Schiemenz, K.; Eichler-Löbermann, B. Biomass ashes and their phosphorus fertilizing effect on different crops. Nutr. Cycl. Agroecosyst. 2010, 87, 471-482. [CrossRef]

25. Vogel, T.; Nelles, M.; Eichler-Löbermann, B. Phosphorus application with recycled products from municipal waste water to different crop species. Ecol. Eng. 2015, 83, 466-475. [CrossRef]

26. Houba, V.J.G.; Novozamsky, I.; Huybregts, A.W.M.; van der Lee, J.J. Comparison of soil extractions by $0.01 \mathrm{M} \mathrm{CaCl}_{2}$, by EUF and by some conventional extraction procedures. Plant Soil 1986, 96, 433-437. [CrossRef]

27. R Core Team. R: A Language and Environment for Statistical Computing; R Foundation for Statistical Computing: Vienna, Austria, 2020.

28. Laird, N.M.; Ware, J.H. Random-Effects Models for Longitudinal Data. Biometrics 1982, 38, 963. [CrossRef] [PubMed]

29. Verbeke, G.; Molenberghs, G. Linear Mixed Models for Longitudinal Data; Springer: New York, NY, USA, 2000; ISBN 978-1-44190300-6.

30. Nakagawa, S.; Schielzeth, H.; O'Hara, R.B. A general and simple method for obtaining R2 from generalized linear mixed-effects models. Methods Ecol. Evol. 2013, 4, 133-142. [CrossRef]

31. Bretz, F.; Hothorn, T.; Westfall, P.H. Multiple Comparisons Using R; Chapman \& Hall/CRC Press: Boca Raton, FL, USA, 2011; ISBN 9781584885740 .

32. Münch, E.V.; Barr, K. Controlled struvite crystallisation for removing phosphorus from anaerobic digester sidestreams. Water Res. 2001, 35, 151-159. [CrossRef]

33. Regueiro, I.; Coutinho, J.; Fangueiro, D. Alternatives to sulfuric acid for slurry acidification: Impact on slurry composition and ammonia emissions during storage. J. Clean. Prod. 2016, 131, 296-307. [CrossRef]

34. Popovic, O.; Hjorth, M.; Jensen, L.S. Phosphorus, copper and zinc in solid and liquid fractions from full-scale and laboratoryseparated pig slurry. Environ. Technol. 2012, 33, 2119-2131. [CrossRef]

35. Cocolo, G.; Hjorth, M.; Zarebska, A.; Provolo, G. Effect of acidification on solid-liquid separation of pig slurry. Biosyst. Eng. 2016, 143, 20-27. [CrossRef]

36. Marcato, C.E.; Pinelli, E.; Pouech, P.; Winterton, P.; Guiresse, M. Particle size and metal distributions in anaerobically digested pig slurry. Bioresour. Technol. 2008, 99, 2340-2348. [CrossRef]

37. Sigurnjak, I.; Michels, E.; Crappé, S.; Buysens, S.; Biswas, J.K.; Tack, F.M.G.; Neve, S.D.; Meers, E. Does acidification increase the nitrogen fertilizer replacement value of bio-based fertilizers? J. Plant Nutr. Soil Sci. 2017, 180, 800-810. [CrossRef]

38. Bachmann, S.; Wentzel, S.; Eichler-Löbermann, B. Codigested dairy slurry as a phosphorus and nitrogen source for Zea mays L. and Amaranthus cruentus L. Z. Pflanz. Bodenk. 2011, 174, 908-915. [CrossRef]

39. Chen, M.; Cui, Y.; Bai, F.; Wang, J. Effect of two biogas residues' application on copper and zinc fractionation and release in different soils. J. Environ. Sci. 2013, 25, 1865-1873. [CrossRef]

40. Prays, N.; Kaupenjohann, M. Initial Effects of Differently Treated Biogas Residues from Municipal and Industrial Wastes on Spring Barley Yield Formation. PLoS ONE 2016, 11, e0154232. [CrossRef] [PubMed]

41. Berg, W.; Hörnig, G.; Türk, M. Güllebehandlung mit Milchsäure. Landtechnik 1998, 53, 378-379.

42. Rengel, Z. Handbook of Plant Growth $\mathrm{pH}$ as the Master Variable, 1st ed.; CRC Press: Boca Raton, FL, USA, 2002; ISBN 978-0-36744707-6.

43. Husted, S.; Thomsen, M.U.; Mattsson, M.; Schjoerring, J.K. Influence of nitrogen and sulphur form on manganese acquisition by barley (shape Hordeum vulgare). Plant Soil 2005, 268, 309-317. [CrossRef]

44. Olsen, S.R.; Kemper, W.D.; Jackson, R.D. Phosphate Diffusion to Plant Roots. Soil Sci. Soc. Am. J. 1962, 26, $222-227$.

45. Mollier, A.; Pellerin, S. Maize root system growth and development as influenced by phosphorus deficiency. J. Exp. Bot. 1999, 50, 487-497. [CrossRef]

46. Vogel, T.; Nelles, M.; Eichler-Löbermann, B. Phosphorus effects of recycled products from municipal wastewater on crops in a field experiment. Plant Soil Environ. 2017, 63, 475-482. [CrossRef] 